\title{
Fast Radiochemical Separation of Am, Pu, Np, U, Pa, Th, Ac and Ra in Heavy lon Reactions with Actinide Targets
}

By A. TURler, F. WegmOlleR, H. R. vON GUNTEN* , Radiochemisches Laboratorium, Universität Bern, CH-3000 Bern 9, Switzerland

K. E. Gregorich, D. LeE, D. C. Hoffman, Nuclear Science Division, Lawrence Berkeley Laboratory, 70A-3307, University of California, Berkeley, California 94720, USA

and M. M. FowLER, Isotope and Nuclear Chemistry Division, Los Alamos National Laboratory, Los Alamos, New Mexico 87545, USA

(Received July 31, 1987)

Heavy ion reactions /Actinide targets / Fast radiochemical separation $/ \mathrm{Ra}$ to $\mathrm{Am}$

\section{Abstract}

A procedure is presented for a relatively fast ( 20 to $30 \mathrm{~min}$ ) separation of trace amounts of americium, plu tonium, nep tunium, uranium, protactinium, thorium, actinium and radium. Isotopes of these elements, produced in heavy ion reactions with actinide targets and collected by recoil in copper catcher foils, can be separated from each other and from contaminating activities. The element fractions were sufficiently clean for determinations by gamma-ray and/or alpha spectroscopy.

\section{Introduction}

In recent years we performed several reaction mechanism studies of heavy ion induced reactions with heavy actinide targets [1-4]. Radiochemical methods have been used throughout these experiments which were performed either at the Lawrence Berkeley Laboratory (LBL), Berkeley, California, USA or at the Gesellschaft für Schwerionenforschung (GSI), Darmstadt, FRG. Some of the chemical procedures used in these experiments were published recently in this jo'ırnal [5]. In an attempt to determine relatively short-lived products (half-lives $>10 \mathrm{~min})$ below the actinide target $\left(Z_{\text {Product }}<Z_{\text {Target }}\right)$ faster procedures were developed and successfully used. These procedures are described in detail in the experimental section.

\section{Experimental}

The recoil products from the heavy ion reactions were collected in copper catcher foils. The chemical processing of the copper foils for the separation and recovery of the products produced during the bombardments is described in the following sections and in Figs. 1-8.

\subsection{Dissolution of the recoil catcher foils and preseparation of the elements}

The copper catcher foil (up to $50 \mathrm{mg}$, usually $15-20 \mathrm{mg}$ ) was dissolved in $1 \mathrm{ml}$ of conc. $\mathrm{HNO}_{3}$ containing $50 \mu \mathrm{l}$ of $70 \% \mathrm{HClO}_{4}$ and appropriate yield tracers (Fig. 1). The

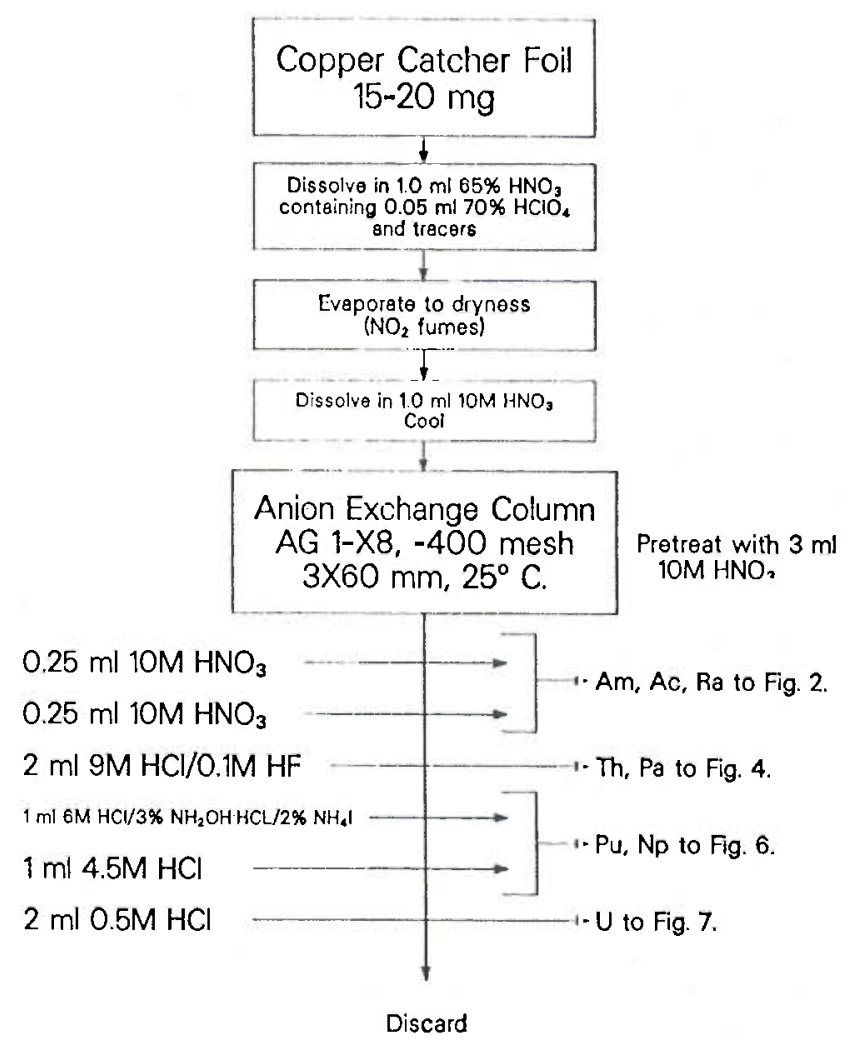

Fig. 1. Dissolution of copper recoil catcher foil and initial separation of elements Am through Ra.

solution was evaporated to dryness until the evolution of $\mathrm{NO}_{2}$ fumes. The residue was dissolved in $1 \mathrm{ml}$ of $10 \mathrm{M}$ $\mathrm{HNO}_{3}$, the resulting solution was cooled to room temperature, transferred to an anion exchange column (AG 1-X8, -400 mesh, $3 \mathrm{~mm} \times 60 \mathrm{~mm}$ ) pretreated shortly before the experiment with $3 \mathrm{ml} 10 \mathrm{M} \mathrm{HNO}_{3}$. The column was washed twice with $0.25 \mathrm{ml}$ of $10 \mathrm{M} \mathrm{HNO}_{3}$ at a flow rate of 10-12 drops/min. The first effluent from the column, containing the trivalent actinides, $\mathrm{Ra}$ and $\mathrm{Cu}$ was used for the determination of $\mathrm{Am}, \mathrm{Ac}$ and $\mathrm{Ra}$. Thorium and $\mathrm{Pa}$ were eluted together with $2.0 \mathrm{ml}$ of $9 \mathrm{M} \mathrm{HCl} / 0.1 \mathrm{M} \mathrm{HF}$. Plutonium and $\mathrm{Np}$ were stripped simultaneously using $1.0 \mathrm{ml}$ of a solution containing $6 \mathrm{M} \mathrm{HCl} / 3 \% \mathrm{NH}_{2} \mathrm{OH} \cdot \mathrm{HCl} /$ $2 \% \mathrm{NH}_{4} \mathrm{I}$ and $1.0 \mathrm{ml}$ of $4.5 \mathrm{M} \mathrm{HCl}$. Finally $\mathrm{U}$ was eluted with $2.0 \mathrm{ml}$ of $0.5 \mathrm{M} \mathrm{HCl}$ [6].

\footnotetext{
* Also at Eidgenössisches Institut für Reaktorfor schung Würenlingen, Switzerland.
} 


\subsection{Separation of americium, actinium and radium}

The $\mathrm{HNO}_{3}$ effluent from the anion column from section 2.1 (Fig. 1) containing the $\mathrm{Cu}, \mathrm{Am}, \mathrm{Ac}$ and $\mathrm{Ra}$ was evaporated to near dryness (Fig. 2). The residue was picked up in $0.5-1.0 \mathrm{ml} 9 \mathrm{M} \mathrm{HCl}$ and loaded on an anion exchange column (AG 1-X8, 200-400 mesh, $10 \mathrm{~mm} \mathrm{x}$ $50 \mathrm{~mm}$ ), pretreated with $9 \mathrm{M} \mathrm{HCl}$ shortly before the experiment. Radium, Ac, Am and other +3 actinides were eluted ahead of the $\mathrm{Cu}$ with $9 \mathrm{M} \mathrm{HCl}$. The fraction containing the Ra, Ac and Am was dried, dissolved in $0.1 \mathrm{ml}$ $\mathrm{H}_{2} \mathrm{O}$ and dried a second time to remove any residual acid. The residue was picked up in $0.2 \mathrm{ml}$ of $0.02 \mathrm{M} \mathrm{HNO}_{3}$ and loaded onto a $2 \mathrm{~mm} \times 50 \mathrm{~mm}$ HDEHP chromatographic column (HDEHP on Celite 535 prepared as in Ref. 7). The $\mathbf{R a}$ along with other ions in +1 or +2 charge states comes off the HDEHP column in the first two free column volumes of $0.02 \mathrm{M} \mathrm{HNO}_{3}$. The Ra fraction was evaporated on a Pt disc for alpha counting. Actinium comes off the HDEHP column in the third free column volume of $0.1 \mathrm{M} \mathrm{HNO}_{3}$ and was collected directly on the top of a cation exchange column. Americium comes off the HDEHP column in the second free column volume of $0.4 \mathrm{M} \mathrm{HNO}_{3}$ and was also collected directly on the top of a cation exchange column. The other +3 actinides can then be eluted with $0.04 \mathrm{M} \mathrm{HCl}$ from this column, if desired.

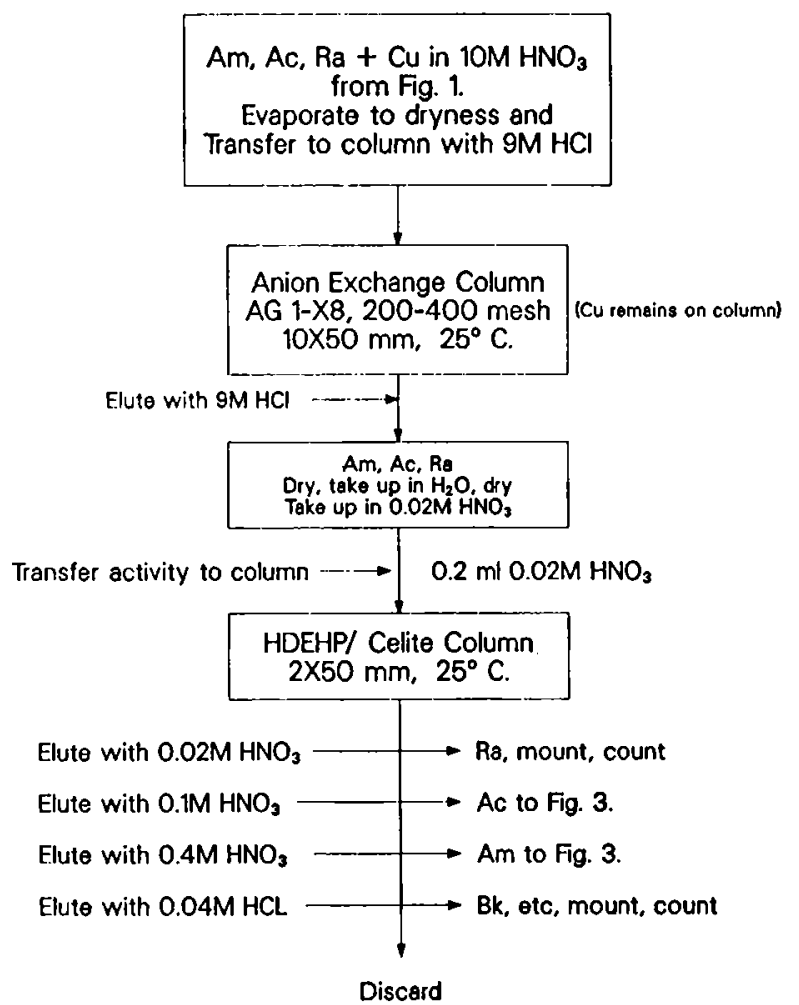

Fig. 2. Separation of Ra, Ac, Am and heavier actinides.

The Ac and Am fractions were passed through their respective cation columns (MP 50, 200-400 mesh, $2 \mathrm{~mm} \times 50 \mathrm{~mm}$ ) and were eluted in the second through fourth free column volumes ahead of the lanthanide activities with freshly saturated $13 \mathrm{M} \mathrm{HCl}$ (Fig. 3). The Ac fraction from the cation column was prepared for alpha and gamma-ray counting by evaporating on a Pt disc. The Am fraction from the cation column was coprecipitated with $\mathrm{LaF}_{3}$. Lanthanum carrier and $\mathrm{Zr} / \mathrm{Ba}$ hold-back carriers were added and $\mathrm{LaF}_{3}$ precipitated with $1 \mathrm{ml}$ of $1 \mathrm{M} \mathrm{HF}$. After five minutes the precipitate was filtered and mounted for gamma counting.

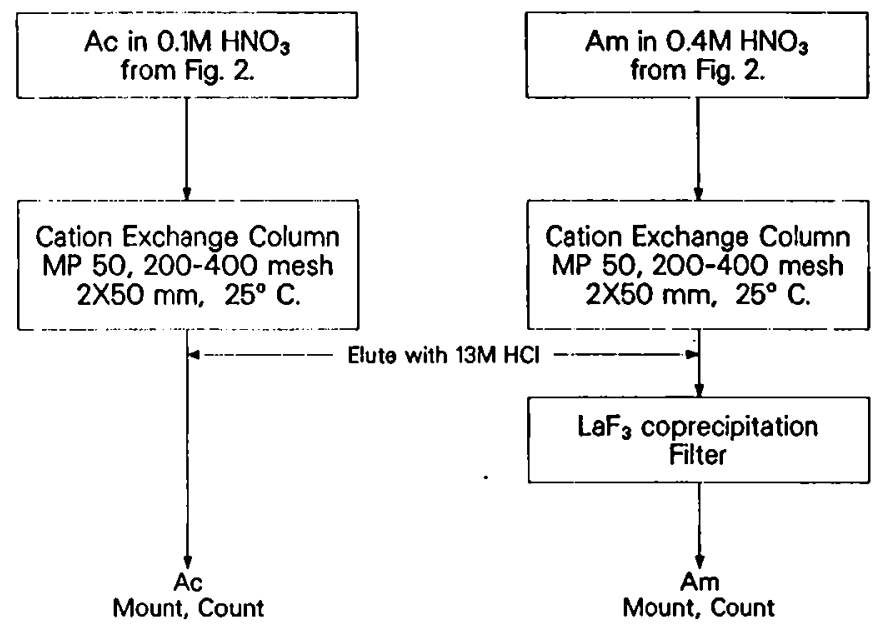

Fig. 3. Purification of the AC and Am fractions.

\subsection{Thorium and protactinium separation}

$0.1 \mathrm{ml}$ of $40 \% \mathrm{HF}$ was added to the column effluent from section 2.1 (Fig. 1) containing $\mathrm{Th}$ and $\mathrm{Pa}$ (Fig. 4). This solution was extracted twice with $2.0 \mathrm{ml}$ of methyl isobutyl ketone [8] which had been pre-equilibrated with $9 \mathrm{M} \mathrm{HCl} / 0.1 \mathrm{M} \mathrm{HF} .10 \mathrm{ml}$ centrifuge tubes with screw caps were used for all extractions. The phases were separated by centrifuging and the organic phase was discarded.

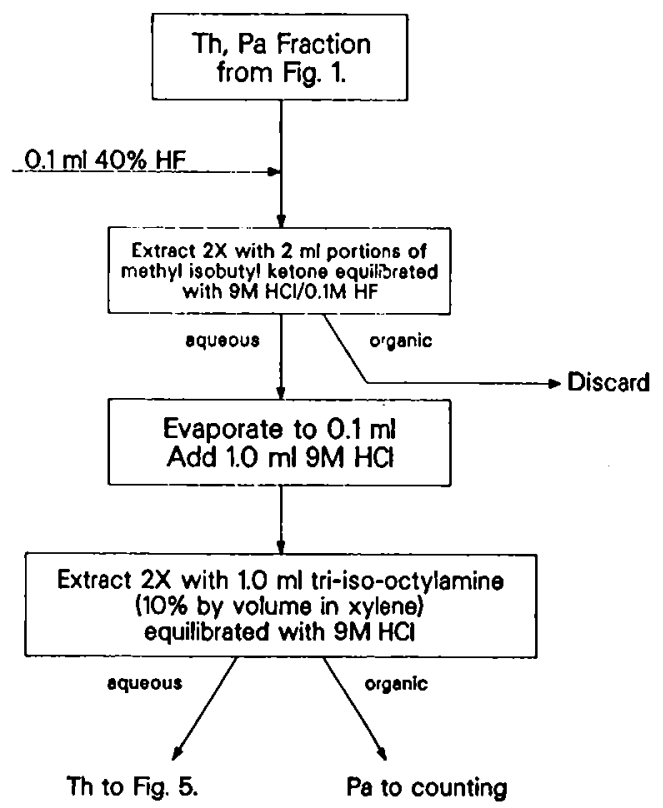

Fig. 4. Separation of $\mathrm{Th}$ and $\mathrm{Pa}$. 
The aqueous phase was evaporated to less than $0.1 \mathrm{ml}$, was taken up in $1.0 \mathrm{ml}$ of $9 \mathrm{M} \mathrm{HCl}$ and $\mathrm{Pa}$ was extracted with two times $1.0 \mathrm{ml}$ of tri-iso-octylamine $(10 \%$ by volume in xylene) [6] which had been pre-equilibrated with $9 \mathrm{M} \mathrm{HCl}$. The organic phases containing the $\mathrm{Pa}$ were combined and gamma counted.

Thorium was extracted from the aqueous phase (Fig. 5) with $1.0 \mathrm{ml}$ of $0.1 \mathrm{M}$ tri-n-octyl-phosphine oxide in cyclohexane [6] which had been pre-equilibrated with $9 \mathrm{M} \mathrm{HCl}$ and was back-extracted twice with $1.0 \mathrm{ml}$ of $0.1 \mathrm{M} \mathrm{HCl} /$ $1 \mathrm{M} \mathrm{HF}$. The aqueous solutions were combined and gamma counted or electroplated for alpha counting (see section 2.6).

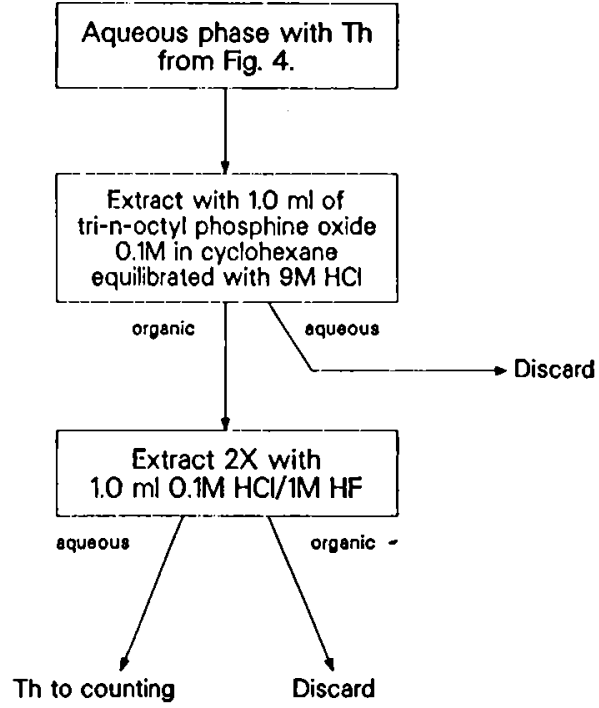

Fig. 5. Purification of the Th fraction.

\subsection{Neptunium and plutonium determ ination}

Neptunium and $\mathrm{Pu}$ from section 2.1 (Fig. 1) were either coprecipitated with $\mathrm{LaF}_{3}$ (Fig. 6) by the method de-

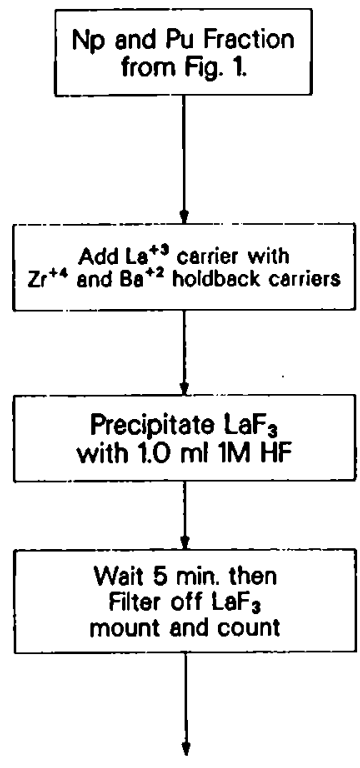

Np and Pu to counting

Fig. 6. Purification of the $\mathrm{Np}$ and $\mathrm{Pu}$ fraction. scribed previously in the Am procedure and mounted for gamma-ray counting or electroplated for alpha counting (see section 2.6).

\subsection{Uranium determination}

$1.0 \mathrm{ml}$ of conc. $\mathrm{HNO}_{3}$ and $0.1 \mathrm{ml} \mathrm{NaNO} \mathrm{N}_{3}(11 \mathrm{wt} \%)$ were added to the column effluent from section 2.1 (Fig. 1) containing the uranium (Fig. 7). This solution was evaporated twice to dryness to minimize the $\mathrm{Cl}^{-}$concentration. The residue was dissolved in $2.0 \mathrm{ml}$ of a solution containing $\mathrm{NaNO}_{3}(11 \mathrm{wt} \%)$ and EDTA $(0.03 \mathrm{wt} \%)$, having a $\mathrm{pH}$ of 2.3. The uranium was extracted with $3.5 \mathrm{ml}$ of triphenyl arsine oxide (1 wt \% in chloroform, preequilibrated with $6 \mathrm{M} \mathrm{HCl}$ ) and back extracted with $3.0 \mathrm{ml}$ of $6 \mathrm{M}$ $\mathrm{HCl}$ [O]. The solution was gamma counted or electroplated for alpha counting (see section 2.6).

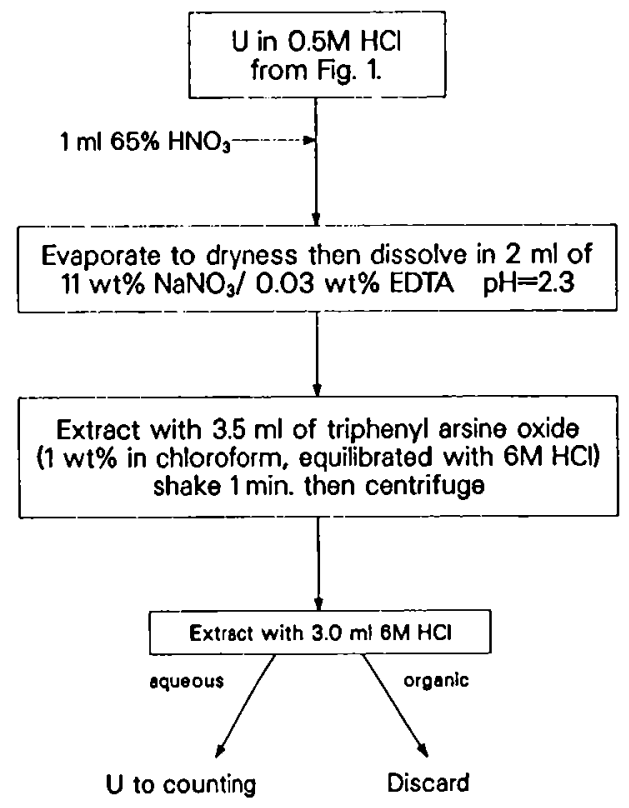

Fig. 7. Purification of the $\mathrm{U}$ fraction.

\subsection{Electroplating of neptunium/plu tonium, uranium and thorium samples}

The electroplating cell used for the preparation of samples suitable for alpha counting is shown in Fig. 8. It was machined from teflon. The two parts were hold together by a ball-joint clamp. A " $O$ "-ring, pressed on to the platinum disk, ensured against leaking. Convection within the solution was accomplished with a stirrer.

\subsubsection{Electroplating of neptunium/plutonium}

The column effluent containing $\mathrm{Np}$ and $\mathrm{Pu}$ from section 2.1 (Fig. 1) was evaporated to dryness several times with $2 \mathrm{ml}$ of conc. $\mathrm{HCl}$. The residue was picked up with $0.1 \mathrm{ml}$ of conc. $\mathrm{HCl}$, and $4 \mathrm{ml}$ of $5 \mathrm{M} \mathrm{NH}_{4} \mathrm{Cl}$ were added. Two 


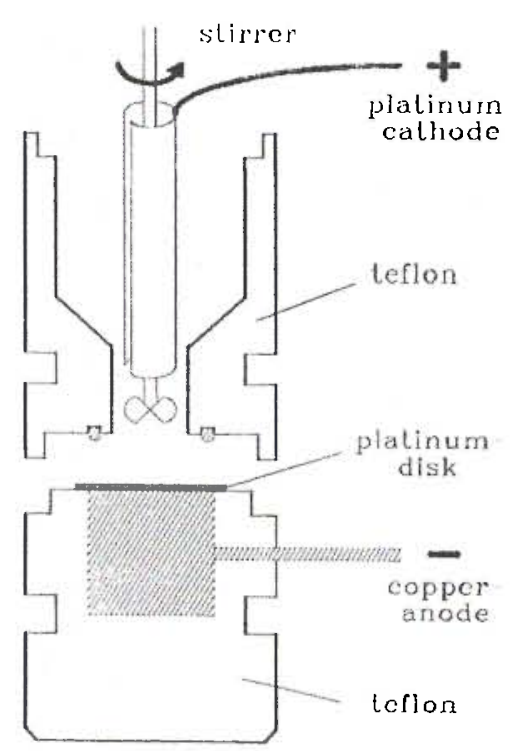

Fig. 8. Electroplating cell. The two parts are held together by it clamp. The inner diameter of the plating cell is $11 \mathrm{~mm}$.

drops of methyl red were added and then $\mathrm{NH}_{4} \mathrm{OH}$ until the solution was basic. The solution was then neutralized with $3 \mathrm{M} \mathrm{HCl}$ to the methyl red end point and electroplated on a platinum disk for 30 minutes in the plating cell. Before using the platinum disk was washed with water and ethanol and flamed. Plating conditions were $5 \mathrm{~V}$ and 2 amperes $/ \mathrm{cm}^{2}$. The solution was stirred during the plating process. Before the end of the electroplating the solution was made basic by adding $1 \mathrm{ml}$ of conc. $\mathrm{NH}_{4} \mathrm{OH}$. The electroly te was removed from the cell, the platinum disk rinsed with water and flamed [10]. Plating yields were $>90 \%$.

\subsubsection{Electroplating of uranium}

The uranium fraction from section 2.5 (Fig. 7) was evaporated several times to dryness after adding $1 \mathrm{ml}$ of conc. $\mathrm{HCl}$. The residue was picked up in $3 \mathrm{ml}$ of $0.01 \mathrm{M}$ $\mathrm{HCl}$ and diluted with $3 \mathrm{ml}$ of $4.2 \mathrm{M} \mathrm{NH}_{4} \mathrm{Cl}$. This solution was electroplated for 40 minutes at $10 \mathrm{~V}$ and 2.5 amperes/ $\mathrm{cm}^{2}$. At the end of the plating process $1 \mathrm{ml}$ of conc. $\mathrm{NH}_{4} \mathrm{OH}$ was added, the electroly te was removed and the platinum disk rinsed with water and flamed. Plating yields were $>\mathbf{8 0} \%$.

\subsubsection{Electroplating of thorium}

Interfering amounts of fluoride in the thorium fraction from section 2.3 (Fig. 5) were removed by adding $100 \mu 1$ of conc. $\mathrm{HClO}_{4}$ and evaporating the solution to less than $0.1 \mathrm{ml}$. The residue was picked up in $1 \mathrm{ml}$ of $10 \mathrm{M} \mathrm{HNO}$ and evaporated to dryness, dissolved in $1 \mathrm{ml}$ of $10 \mathrm{M} \mathrm{HNO}_{3}$ and passed through an anion exchange column (AG 1-X8, $-400 \mathrm{mesh}, 3 \mathrm{~mm} \times 60 \mathrm{~mm}$ ) pretreated with $3 \mathrm{ml}$ of $10 \mathrm{M}$ $\mathrm{HNO}_{3}$. Thorium was eluted with $3 \mathrm{ml}$ of $9 \mathrm{M} \mathrm{HCl}$. This solution was evaporated to dryness and taken up with $1 \mathrm{ml}$ of conc. $\mathrm{HCl}$, evaporated to dryness and the residue picked up in $0.1 \mathrm{ml}$ of conc. $\mathrm{HCl}$. Four milliliters of $5 \mathrm{M}$ $\mathrm{NH}_{4} \mathrm{Cl}$ were added and the solution was electroplated under the same conditions as described for $\mathrm{Pu}$ and $\mathrm{Np}$. Plating yields were $>90 \%$.

\subsection{General}

Twenty to thirty minutes were required for the entire procedure (without the electroplating step) if three to four experimenters worked simultaneously on the separation, purification and preparation of the samples. The chemical yields of the separations were determined by the added yield tracers. Depending on the nuclides of interest suitable tracers had to be selected. The usual overall chemical yields for the investigated elements where: Am 95\%, Pu $85 \%$, Np $85 \%$, U 50\%, Pa 55\%, Th $40 \%$, Ac 50\%, Ra $50 \%$.

\section{Acknowledgment}

This work was supported in part by the U.S. Department of Energy under Contracts Nos. DE-AC03-76SF 00098 and W-7405-ENG 36 and by the Swiss National Science Foundāion.

\section{References}

1. LEE, D., VON GUNTEN, H. R., JACA K, B., NURMIA, M., LIU, Y. F., LUO, C., SEA BORG, G. T., HOFFMAN, D. C.: Phys. Rev. C 25, 286 (1982).

2. LEE, D., MOODY, K. J., NURMIA, M. J., SEA BORG, G. T., VON GunTen, H. R., HOfFMan, D. C.: Phys. Rev. C27, 2656 (1983).

3. HOFFMAN, D. C., FOWLER, M. M., DANIELS, W. R., VON GUNTEN, H. R., LEE, D., MOODY, K. J., GREGORICH, K. E., WELCH, R. B., SEABORG, G. T., BRUCHLE, W., BRUGGER, M., GÄGGE LER, H. W., SCHÄDEL, M., SUM MERER, K., WIRTH, G., BLAICH, TH., HERRMANN, G., HILDEBRAND, N., KRAT Z, J. V., LERCH, M., TRA UTMANN, N.: Phys. Rev. C31, 1763 (1985).

4. GẌGGELER, H. W., BRUCHLE, W., BRUGGER, M., SCHÄDEL, M., SUMMERER, K., WIRTH, G., KRAT Z, J. V., LERCH, M., BLAICH, TH., HER RMANN, G., HILDEBRAND, N., TRAUTMANN, N., LEE, D., MOODY, K. J., GREGORICH, K. E., WELCH, R. B., SEABORG, G. T., HOFFMAN, D. C., DANIE LS, W. R., FOWLER, M. M., VON GUNTEN, H. R.: Phys. Rev. C 33, 1983 (1986).

5. FOWLER, M. M., DANIE LS, W. R., VON GUNTEN, H. R., GÄGG ELER, H. W., HOFFMAN, D. C., LEE, D., GREGORICH, K. E., MOODY, K. J., LERCH, M., HER RMANN, G. TRA UTMANN, N.: Radiochim. Acta 40, 75 (1986).

6. GINDLER, J. E.: NAS-NS 3050 (1962).

7. GREGORICH, K. E.: LBL 20192 (1985).

8. FLYNN, K. F.: ANL-75-24 (1975).

9. KEIL, R.: Fresenius Z. Anal. Chem. 292, 13 (1978).

10. MIT CHELL, R. F.: Anal. Chem. 32, 326 (1960). 